\title{
PROGRESS REPORT ON THINNING AND GIRDLING EXPERIMENTS IN CANADA
}

\author{
By J. M. Gibson
}

T THIS report will be briefly covered the sources of information so far contacted with reference to thinning and girdling experiments.

The Maritime Provinces investigations and studies on thinning and girdling have been carried out by the Dominion Forest Service, and a summary of the results is being prepared by Mr. J. C. Veness of the Dominion Forest Service at Fredericton.

Quebec reports that some experimental thinnings were carried out in 1921 in the Township Reserve of Parke and on the nursery forest at Berthierville, but no remeasurements have been made. Further work is contemplated in connection with the property of the Ranger School at Duchesney.

The Dominion Forest Service have compiled results of their experiments at Petawawa, Ontario, and Valcartier, Quebec, in addition to their work in the Maritimes.

Manitoba's thinning is confined to sample plots on the Duck Mountain, Spruce Woods and Sandilands Forest Reserves, and no conclusions are drawn.

Saskatchewan has submitted reports covering work in the Cypress Hills Forest and the Nisbet Provincial Forest.

British Columbia has submitted a report on thinnings in Douglas Fir and made by Mr. Schenstrom for the B.C. Forest Service, and a report on thinnings in hemlock made by the same investigator for the B.C. Pulp and Paper Co. Ltd.

The data collected to date was nearly all the result of Dominion or Pro. vincial Government experiments and it is felt that there must be additional data in this field gathered by private industry.

We are very anxious to contact this source of information and would appreciate very much if our members would forward me any information they may know of and would care to have incorporated in a summary of thinning and girdling experiments. 